OPEN ACCESS

Edited by:

Dongze Zhang

University of Nebraska Medical

Center, United States

Reviewed by:

Julia Shanks,

The University of Auckland,

New Zealand

Roger Lyrio Santos,

Federal University of Espirito Santo,

Brazil

*Correspondence:

Rafael M. Costa

rafael_menezes@ufj.edu.br

Rita C. Tostes

rtostes@usp.br

Specialty section:

This article was submitted to

Vascular Physiology,

a section of the journal

Frontiers in Physiology

Received: 16 December 2021 Accepted: 31 January 2022

Published: 08 March 2022

Citation:

Costa RM, Alves-Lopes R, Alves JV, Servian CP, Mestriner FL,

Carneiro FS, Lobato NS and

Tostes RC (2022) Testosterone Contributes to Vascular Dysfunction in Young Mice Fed a High Fat Diet by Promoting Nuclear Factor E2-Related

Factor 2 Downregulation and Oxidative Stress.

Front. Physiol. 13:837603. doi: 10.3389/fphys.2022.837603

\section{Testosterone Contributes to Vascular Dysfunction in Young Mice Fed a High Fat Diet by Promoting Nuclear Factor E2-Related Factor 2 Downregulation and Oxidative Stress}

Rafael M. Costa ${ }^{1,2 *}$, Rhéure Alves-Lopes ${ }^{1,3}$, Juliano V. Alves ${ }^{1}$, Carolina P. Servian', Fabiola L. Mestriner ${ }^{1}$, Fernando S. Carneiro ${ }^{1}$, Núbia de S. Lobato ${ }^{2}$ and Rita C. Tostes ${ }^{1 *}$

${ }^{1}$ Department of Pharmacology, Ribeirão Preto Medical School, University of São Paulo, Ribeirão Preto, Brazil, ${ }^{2}$ Academic Unit of Health Sciences, Federal University of Jatai, Jatai, Brazil, ${ }^{3}$ British Heart Foundation, Glasgow Cardiovascular Research Centre, Institute of Cardiovascular and Medical Sciences, University of Glasgow, Glasgow, United Kingdom

Obesity, an important risk factor for cardiovascular disease, promotes vascular oxidative stress. Considering that free testosterone levels remain within the reference range, especially in obese young men and that testosterone stimulates reactive oxygen species (ROS) generation, we sought to investigate whether testosterone interferes with obesityassociated oxidative stress and vascular dysfunction in male mice. We hypothesized that testosterone favors ROS accumulation and vascular dysfunction in high fat diet (HFD)-fed obese mice. We also questioned whether testosterone downregulates the nuclear factor E2-related factor 2 (Nrf2), one of the major cellular defense mechanisms against oxidative stimuli. Male C57BI/6J mice were submitted to orchiectomy or sham-operation. Mice received either a control diet (CD) or HFD for 18 weeks. Vascular function was assessed in thoracic aortic rings and molecular mechanisms by which testosterone contributes to vascular dysfunction were determined. HFD reduced acetylcholine-induced vasodilation and increased vascular ROS generation in sham mice. Castration prevented these effects. Treatment of castrated mice fed either the CD or HFD with testosterone propionate decreased acetylcholine vasodilation. HFD decreased Nrf2 nuclear accumulation, events linked to decreased mRNA expression and activity of Nrf2-regulated enzymes (catalase, heme oxygenase-1, peroxiredoxin, and thioredoxin). These events were prevented in HFD-fed castrated mice. Bardoxolone, a Nrf2 activator, increased nuclear accumulation of Nrf2, decreased ROS generation and improved acetylcholine vasodilation in HFD-fed sham mice. In vitro, testosterone increased ROS generation and decreased Nrf2 nuclear accumulation. These effects were prevented in the presence of an androgen receptor antagonist, an inhibitor of gene transcription and an inhibitor of the pro-oxidant enzyme NOX-1. These results indicate that testosterone downregulates Nrf2, leading to oxidative stress and vascular dysfunction in HFD-fed obese young mice.

Keywords: obesity, testosterone, vascular dysfunction, Nrf2, oxidative stress 


\section{HIGHLIGHTS}

- Testosterone contributes to vascular dysfunction in young obese.

- Vascular dysfunction in young obese is associated with testosterone-induced oxidative stress.

- Testosterone contributes to decreased Nrf2 transcriptional factor signaling, compromising the antioxidant function in the vascular system.

- The decrease in testosterone levels during the development of obesity in young individuals attenuates oxidative stress, improving the performance of the transcription factor Nrf2 and consequent prevention of vascular dysfunction.

\section{INTRODUCTION}

Obesity is a major cause of morbidity and mortality in a large part of the world population (Andersson and Vasan, 2018; Csige et al., 2018). Numerous comorbid conditions are associated with adult obesity, including type 2 diabetes mellitus, arterial hypertension, and other cardiovascular and metabolic disorders (Krauss et al., 1998; Kahn et al., 2006; Jiang et al., 2016; Costa et al., 2018). Excessive fat accumulation is widely considered the result of interactions between environmental, genetic and epigenetic factors, which disturb the balance between the caloric intake and energy expenditure, leading to increased risk of illness (Hill, 2006). The prenatal period and the first years of an individual's life were identified as critical phases for the development of body composition (Stettler and Iotova, 2010). High birth weight is associated with an increased risk of obesity in adulthood (Yu et al., 2011; Zhao et al., 2012). Furthermore, faster weight gain in children is also associated with an increased risk of overweight and obesity later in life (Monteiro and Victora, 2005; Ong and Loos, 2006; Druet et al., 2012). Fat deposition in childhood and early adulthood also accounts for increased cardiovascular risk (Nadeau et al., 2011; Caprio et al., 2020). However, it is unclear how body mass gain during the transition from early to middle adulthood, when most body mass gain occurs, relates to subsequent health consequences.

One important factor that has been associated with both childhood and adult obesity are testosterone levels (Kelly and Jones, 2013; Mancini et al., 2021). Nevertheless, little attention has been directed toward the role of androgenic steroids on the mechanisms of cardiovascular and metabolic alterations in obesity. Although still a controversial topic, androgens are widely associated with higher risk of cardiovascular disease in men. In fact, abusive use of synthetic androgens by athletes leads to premature cardiovascular complications and the male gender itself is an independent risk factor for cardiovascular disease (Kloner et al., 2016). In addition, there is abundant epidemiological and clinical evidence linking a decline in testosterone levels with vascular dysfunction, atherosclerotic process, stroke and cardiovascular mortality (Bhasin and Herbst, 2003; Lopes et al., 2012; Alves et al., 2020). One explanation for the lack of agreement amongst these studies is that testosterone may shift target tissues susceptibility to damage by mechanisms that depend on the concentration, duration and source (exogenous androgen, salt of testosterone), as well as the age, sex and health/disease state of the individual undergoing testosterone treatment.

Oxidative stress, a disturbance in the balance between the production of free radicals and antioxidant defenses, plays a critical role in the pathophysiology of obesity and obesity-associated complications (Betteridge, 2000). Obesity itself induces systemic oxidative stress through mechanisms that involve superoxide anion generation from NADPH oxidases, oxidative phosphorylation, and chronic inflammation. Adipose tissue dysfunction in obesity leads to increased reactive oxygen species (ROS) generation and inadequate cellular antioxidant defense (Furukawa et al., 2004; Zhou et al., 2021). In the cardiovascular system, oxidative stress occurs concomitantly with endothelial dysfunction, increased vascular contractility, growth and apoptosis of vascular smooth muscle cells (VSMC), lipid peroxidation and increased extracellular matrix protein deposition (da Costa et al., 2017; Costa et al., 2018). Testosterone and its metabolites affect the main components that control/modulate ROS generation and degradation (Tostes et al., 2016). Testosterone induces ROS generation in VSMC via NADPH oxidases, with greater production in cells from hypertensive compared with normotensive animals (Chignalia et al., 2012). Testosterone also induces mitochondria-derived ROS generation and apoptosis in VSMC, effects mediated via androgen receptor activation (Lopes et al., 2014). Testosterone stimulates the generation of superoxide anion (via xanthine oxidase) and nitric oxide, increasing peroxynitrite production and stimulating apoptosis (Puttabyatappa et al., 2013). Cyclooxygenase2-dependent ROS production is obligatory for testosterone-induced immune cells migration (Chignalia et al., 2015), which may contribute to inflammation and target organ damage. Collectively, these data indicate that in oxidative conditions, androgen signaling further increases cell damage.

Antioxidants are compounds or enzymatic systems that scavenge or neutralize free radicals (Kawagishi and Finkel, 2014). In this sense, the nuclear factor E2-related factor 2 (Nrf2) is one of the major defense mechanisms against oxidative and proteotoxic stress in cells (Cuadrado et al., 2019). Under physiological conditions, Nrf2 is usually associated with Keap-1, a repressor protein found in the cytoplasm (Horie et al., 2021). Stressors, such as free radicals, favor the translocation of Nrf2 to the cell nucleus. The accumulation of nuclear Nrf2 allows its binding to the antioxidant response element of genes that code antioxidant proteins (Nguyen et al., 2009). Growing evidence indicates that decreased or defective Nrf2 activity contributes to oxidative stress, favoring the pathophysiology of cardiovascular disorders found in obesity (da Costa et al., 2019).

While it is clear that testosterone regulates ROS generation, it is undefined whether male sex hormones contribute to the progressive vascular oxidative damage caused by obesogenic diets. In this study, we questioned whether loss of androgens in young male mice changes the tissue's hormonal landscape, yielding a vascular oxidative status that differs from that observed in adult males. Accordingly, we used castrated young male mice 
to determine whether androgens confer protection or exacerbate vascular oxidative damage induced by an obesogenic diet. We hypothesized that testosterone, signaling through androgen receptors, negatively impacts $\mathrm{Nrf} 2 / \mathrm{Keap} 1$ signaling. We also determined whether testosterone treatment changes Nrf2/Keap1 signaling. Finally, we determined in vitro effects of testosterone on ROS generation and Nrf2 nuclear accumulation, using endothelial cells treated with vehicle or the androgen receptor antagonist flutamide. Alternatively, the functional and molecular components were measured in the presence of vehicle or the Nrf2 activator bardoxolone.

\section{MATERIALS AND METHODS}

\section{Animals, Orchiectomy, and Diets}

All experimental protocols were performed in accordance with the recommendations of the Brazilian Guidelines for the Care and Use of animals for Scientific and Teaching Purposes and the Guidelines for the Practice of Euthanasia (CONCEA-MCT, 2013), having been approved by the Ethics Committee on Animal Use of the University of São Paulo, Ribeirão Preto, Brazil (Protocol n ${ }^{\circ}$ 206/2016).

Four-week-old male $\mathrm{C} 57 \mathrm{Bl} / 6 \mathrm{~J}$ mice were obtained and maintained in the Animal Facility of the University of São Paulo, Ribeirão Preto, Brazil on 12-h light/dark cycles under controlled temperature $\left(22 \pm 1^{\circ} \mathrm{C}\right)$ and humidity (50-60\%) with ad libitum access to food and water. Mice were anesthetized (ketamine and xylazine at doses of 75 and $15 \mathrm{mg} / \mathrm{kg}$, respectively, intraperitoneally), the efferent duct of each testicle was ligated, and the testicles were removed. Sham mice were submitted to the same surgical procedures without efferent duct ligation or testicles removal. After a 1-week acclimatization period, mice were divided into two groups: (1) mice maintained on a control diet [CD (protein 22\%, carbohydrate $70 \%$, and fat $8 \%$ of energy, PragSolucoes)], and (2) mice receiving a highfat diet [HFD (protein 10\%, carbohydrate 25\%, and fat $65 \%$ of energy, PragSolucoes)]. After 18 weeks on the CD or HFD, mice were euthanized by carbon dioxide $\left(\mathrm{CO}_{2}\right)$ inhalation without removing mice from their home cage. Death was confirmed by cardiac arrest. Studies followed the ARRIVE guidelines for reporting experiments on experimental animals.

\section{Biochemical Profile}

Glucose levels were determined using a glucose analyzer (AccuCheck, Roche Diagnostics). Total cholesterol and triglyceride concentrations were determined in serum samples from mice fasted for $12 \mathrm{~h}$ (da Costa et al., 2018), by enzymatic colorimetric method (Doles ${ }^{\circledR}$ ). Plasma insulin concentration $(\mathrm{ng} / \mathrm{mL})$ was determined by radioimmunoassay (Insulin $\mathrm{Kit}^{\circledR}$ ).

\section{Testosterone Replacement and Plasma Measurement}

Plasma testosterone levels were determined in sham, castrated and testosterone-treated mice using the IMMULITE 1000 Immunoassay System (Enzo Life Sciences ${ }^{\circledR}$, New York, NY,
United States). After 18 weeks on the CD or HFD, testosteronetreated mice received intramuscular injections of testosteronepropionate [dissolved in peanut oil, $5 \mathrm{mg} / \mathrm{kg}$ body weight per day (Sigma Aldrich, San Luis, MO, United States)], for 15 days.

\section{Assessment of Vascular Function}

Thoracic aorta was rapidly removed, transferred to an ice-cold $\left(4^{\circ} \mathrm{C}\right)$ Krebs Henseleit-modified solution [(in M) $130 \mathrm{NaCl}, 14.9$ $\mathrm{NaHCO}_{3}, 4.7 \mathrm{KCl}, 1.18 \mathrm{KH}_{2} \mathrm{PO}_{4}, 1.17 \mathrm{MgSO}_{4} \cdot 7 \mathrm{H}_{2} \mathrm{O}, 5.5$ glucose, $1.56 \mathrm{CaCl}_{2} \cdot 2 \mathrm{H}_{2} \mathrm{O}$ and 0.026 EDTA] gassed with $5 \% \mathrm{CO}_{2}$ and $95 \%$ $\mathrm{O}_{2}$ to maintain a $\mathrm{pH}$ of 7.4 , and dissected into $2 \mathrm{~mm}$ rings. Aortic rings were mounted in a wire myograph to measure isometric tension, as previously described (da Costa et al., 2017). Vessels were allowed to equilibrate for about $30 \mathrm{~min}$ in Krebs Henseleit solution. After the stabilization period, endothelial function was assessed by testing the relaxant effect of acetylcholine (ACh, $\left.10^{-6} \mathrm{M}\right)$ on vessels contracted with phenylephrine $\left(\mathrm{PE}, 10^{-7} \mathrm{M}\right)$. Aortic rings exhibiting a vasodilator response to ACh greater than $70-80 \%$ were considered endothelium-intact vessels. Cumulative concentration-response curves to $\mathrm{ACh}\left(10^{-10}\right.$ to $\left.10^{-4} \mathrm{M}\right)$ were performed in aortic rings from the various experimental groups.

Relaxation responses to $\mathrm{ACh}$ were also determined after incubation with either the selective superoxide anion $\left(\mathrm{O}_{2}{ }^{-}\right)$ scavenger tiron $\left(10^{-4} \mathrm{M}, 30 \mathrm{~min}\right)$ or the Nrf2 activator bardoxolone $\left(10^{-6} \mathrm{M}, 3 \mathrm{~h}\right)$. Each vascular preparation was tested with a single agent.

\section{Cultured Endothelial Cells and Experimental Design}

Endothelial cells were commercially purchased. An immortalized line of human umbilical vein endothelial cells, EA.hy926, $\left(\right.$ ATCC $^{\circledR}$ CRL-2922 ${ }^{\mathrm{TM}}$ ) was used. Cells were cultured in Dulbecco's Modified Eagle Medium (DMEM) supplemented with $10 \%$ fetal bovine serum (FBS) in a $\mathrm{CO}_{2}$ incubator, at $37^{\circ} \mathrm{C}, 5 \%$ $\mathrm{CO}_{2}$. After confluence, cells were maintained in the presence of 2\% FBS (Rodrigues et al., 2021). Cells were stimulated with testosterone for various times $\left(10^{-7} \mathrm{M}, 15 \mathrm{~min}\right.$ to $\left.6 \mathrm{~h}\right)$. To determined testosterone effects on NADPH oxidase activity, cells were preincubated with a NOX1 inhibitor ML171 $\left(10^{-4}\right.$ $\mathrm{M}, 1 \mathrm{~h})$. To investigate genomic and non-genomic effects of testosterone, cells were incubated with the androgen receptor antagonist flutamide $\left(10^{-5} \mathrm{M}, 1 \mathrm{~h}\right)$ and the gene transcription inhibitor actinomycin $\mathrm{D}\left(10^{-5} \mathrm{M}, 1 \mathrm{~h}\right)$, respectively, previous to exposure to testosterone.

\section{Measurement of Reactive Oxygen Species Dihydroethidium}

Reactive Oxygen Species generation was assessed by dihydroethidium (DHE), as previously described (Costa et al., 2016). Aortas were embedded in the optimal cutting temperature $\left(\mathrm{OCT}^{\mathrm{TM}}\right)$ embedding medium and stored at $-80^{\circ} \mathrm{C}$. Fresh-frozen specimens were cross-sectioned at $10 \mu \mathrm{m}$ thickness and placed on slides covered with poly-(L-lysine). Tissues were loaded with the non-selective dye for ROS detection DHE $\left(5 \times 10^{-6} \mathrm{M}\right.$ in phosphate buffer $\left.10^{-6} \mathrm{M}\right)$ for $30 \mathrm{~min}$ at 
$37^{\circ} \mathrm{C}$. Images were collected on a ZEISS microscope and the results are expressed as fold changes relatively to the control. Fluorescent images were analyzed by measuring the mean optical density of the fluorescence in a computer system (Image J software) and normalized by the area.

\section{Amplex Red}

Thoracic aortae were frozen, macerated and centrifuged. Fifty $\mu \mathrm{L}$-aliquots of the supernatant were removed and hydrogen peroxide $\left(\mathrm{H}_{2} \mathrm{O}_{2}\right)$ was determined fluorometrically by measuring Amplex Red $\left(8 \times 10^{-6} \mathrm{M}\right)$ conversion (Molecular Probes, Invitrogen, Carlsbad, CA, United States) to the fluorescent compound resorufin, in the presence of horseradish peroxidase (4 U/mL). Resorufin fluorescence was detected in a plate fluorimeter (Synergy ${ }^{\mathrm{TM}} 2$ Multi-Detection Microplate Reader, BioTek Instruments, Santa Clara, CA, United States) using excitation and emission wavelengths of 530 and $590 \mathrm{~nm}$, respectively. The fluorescence values were normalized by the total amount of tissue proteins.

\section{Lucigenin}

Generation of $\mathrm{O}_{2}{ }^{-}$was measured by lucigenin luminescence using NADPH as the substrate. Aortae from control and obese mice were homogenized in an assay buffer $(50 \mathrm{mM}$ $\mathrm{KH}_{2} \mathrm{PO}_{4}, 1 \mathrm{mM}$ EGTA, and $150 \mathrm{mM}$ sucrose, $\mathrm{pH}$ 7.4) with a glass-to-glass homogenizer. $100 \mu \mathrm{L}$ of sample, lucigenin (5 $\mu \mathrm{M})$, NADPH $(0.1 \mathrm{mM})$ and assay buffer were used. Luminescence was measured for 30 cycles of $18 \mathrm{~s}$ each, in a luminometer (Orion II Luminometer, Berthold Detection Systems, Pforzheim, Germany). Basal readings were obtained and the reaction was started by the addition of the substrate. Basal and buffer blank values were subtracted from the NADPH-derived luminescence. $\mathrm{O}_{2}{ }^{-}$was expressed as relative luminescence units (RLU)/mg protein.

\section{Measurement of Thiobarbituric Acid Reactive Substances}

Thiobarbituric acid reactive substances (TBARS) concentration was determined colorimetrically (at $540 \mathrm{~nm}$ ) in aortas homogenates with a commercially available kit (\#10009055, Cayman Chemical, United States), following the manufacturer's instructions. TBARS concentration was determined using a standard curve of malondialdehyde and the results are expressed as $\mu \mathrm{M} / \mathrm{mg}$ protein.

\section{NOx}

Plasma nitrate concentrations were determined by subtracting the nitrite values from the NOx values (nitrite + nitrate). For the determination of $\mathrm{NO} x$, the Griess reaction was used. Plasma samples were incubated with nitrate reductase, at $37^{\circ} \mathrm{C}$ for $12 \mathrm{~h}$, in a light-free environment. The Griess reagent was added and reading was performed by spectrophotometry at $540 \mathrm{~nm}$.

\section{Thioredoxin Reductase, Superoxide Dismutase, and Catalase Activities}

Thioredoxin reductase (TrxR) activity was determined in aortas using a commercially available kit (\#CS0170, Sigma-Aldrich, San
Luis, MO, United States). Enzymatic activity was assessed by determining the difference between the time-dependent increase in absorbance at $412 \mathrm{~nm}$ in the presence of the TrxR activity inhibitor from total activity. One activity unit equaled $1 \mathrm{mM} 5^{\prime}$ thionitrobenzoic acid formed/mg protein. Thoracic aortae were homogenized in $300 \mu \mathrm{L}$ of Krebs Henseleit and centrifuged at $18,000 \times g$ for $15 \mathrm{~min}$ at $4^{\circ} \mathrm{C}$. The supernatants were analyzed for superoxide dismutase (SOD) or catalase (CAT) activities. SOD activity was evaluated using a commercially available kit (\#19160, Sigma-Aldrich, San Luis, MO, United States). The results were normalized for protein concentration, and SOD activity is expressed as \% inhibition rate/mg protein. CAT activity was assayed by $\mathrm{H}_{2} \mathrm{O}_{2}$ consumption and measured in a spectrophotometer at $240 \mathrm{~nm}$. One CAT unit (U) was defined as the amount of enzyme required to decompose $1 \mu \mathrm{M}$ of $\mathrm{H}_{2} \mathrm{O}_{2} / \mathrm{min} / \mathrm{mg}$ protein.

\section{Nuclear Factor E2-Related Factor 2 Activity}

To determine nuclear accumulation of Nrf2, the nuclear fraction from cell or tissue lysates were separated using the Active Motif nuclear extract kit (Active Motif, Carlsbad, CA, United States) following the manufacturer's protocol. Cells or tissue were resuspended in 1X hypotonic buffer and centrifuged for $30 \mathrm{~s}$ at $12,800 \times g$ at $4^{\circ} \mathrm{C}$. Nuclear pellets were resuspended in lysis buffer provided by the manufacturer. The suspension was incubated for $30 \mathrm{~min}$ on ice on a rocking platform set at $5 \times g$ and then centrifuged for $10 \mathrm{~min}$ at $12,800 \times g$. The supernatant was transferred to a pre-chilled microcentrifuge tube. Trans $\mathrm{AM}^{\mathrm{TM}}$ Nrf2 ELISA kit (Active Motif) was used to measure nuclear accumulation of Nrf2 at a wavelength of $450 \mathrm{~nm}$.

\section{Quantitative Real-Time Reverse Transcription-Polymerase Chain Reaction}

Total RNA was isolated from aortae using Trizol $^{\circledR}$ (Invitrogen, Carlsbad, CA, United States). RNA was treated with DNAse I (1 U/ $\mu \mathrm{L}$, Promega) and used for firststrand cDNA synthesis, accordingly to the manufacturer instructions. mRNA levels were quantified in triplicate by qPCR StepOnePlus ${ }^{\mathrm{TM}}$ Life Technologies. Specific primers $\left(\mathrm{TaqMan}^{\mathrm{TM}}\right)$ for RT-qPCR were as follows: mouse SOD-1 [Mm01344233_g1], Catalase [Mm00437992_m1], Heme oxygenase-1 [Mm00516005_m1], Peroxiredoxin-1 [Mm01621996_s1] and $\beta$-actin [Mm00607939_s1], purchased from Life Technologies. PCR cycling conditions included $10 \mathrm{~min}$ at $95^{\circ} \mathrm{C}$, followed by 40 cycles at $95^{\circ} \mathrm{C}$ for $15 \mathrm{~s}, 60^{\circ} \mathrm{C}$ for $1 \mathrm{~min}$, and $72^{\circ} \mathrm{C}$ for $60 \mathrm{~s}$. Dissociation curve analysis confirmed that signals corresponded to unique amplicons. Specific mRNA expression levels were normalized relatively to $\beta$-actin mRNA levels using the comparative $\Delta \Delta \mathrm{Ct}$ method.

\section{Western Blot Analysis}

Aortas were frozen in liquid nitrogen and homogenized in a lysis buffer $[50 \mathrm{mM}$ Tris/ $\mathrm{HCl}, 150 \mathrm{mM} \mathrm{NaCl}, 1 \%$ Nonidet P40, $1 \mathrm{mM}$ ethylenediaminetetraacetic acid (EDTA), 1 
$\mu \mathrm{g} / \mathrm{mL}$ leupeptin, $1 \mu \mathrm{g} / \mathrm{mL}$ pepstatin, $1 \mu \mathrm{g} / \mathrm{mL}$ aprotinin, $1 \mathrm{mM}$ sodium orthovanadate, $1 \mathrm{mM}$ phenylmethylsulphonyl fluoride (PMSF), and $1 \mathrm{mM}$ sodium fluoride]. The tissue extracts were centrifuged, and total protein content was quantified using the Bradford method (Bradford, 1976). Proteins (40 $\mu \mathrm{g}$ ) were separated by electrophoresis on $10 \%$ polyacrylamide gel, and transferred on to nitrocellulose membranes. Nonspecific binding sites were blocked with $5 \%$ bovine serum albumin (BSA) in Tris-buffered saline (TBS) containing 0.1\% Tween 20 (for $1 \mathrm{~h}$ at $24^{\circ} \mathrm{C}$ ). Membranes were incubated with antibodies (at the indicated dilutions) overnight at $4^{\circ} \mathrm{C}$. Antibodies were used as follows: anti-keap1 (1:1,000 dilution; Abcam), anti-NOX1 (1:1,000 dilution; Cell Signaling), antiNOX4 (1:1,000 dilution; Cell Signaling), anti-ßactin (1:1,0,000 dilution; Sigma), and anti-GAPDH (1:10,000 dilution; Sigma). After incubation with secondary antibodies, signals were obtained by chemiluminescence, visualized by autoradiography and quantified densitometrically.

\section{Data and Statistical Analyses}

The individual concentration-response curves were fitted into a curve by non-linear regression analysis. $p \mathrm{D}_{2}$ (defined as the negative logarithm of the $\mathrm{EC}_{50}$ values) and maximal response (Emax) were compared by Two-way ANOVA with Bonferroni post-test. The results of the molecular experiments were analyzed by Mann Whitney test or Two-way ANOVA, followed by the Bonferroni post-test. Data were assessed for normality with Shapiro-Wilk test. The Prism software, version 9.0 (GraphPad Software Inc., San Diego, CA, United States) was used to analyze these parameters as well as to fit the sigmoidal curves. Data are presented as mean \pm SEM. $N$ represents the number of mice used. $p$ values less than 0.05 were considered significant.

\section{RESULTS}

\section{The High Fat Diet Effects on Adiposity in Young Mice Is Not Under the Influence of Testosterone}

Table 1 details the characteristics of the animal groups. At the beginning of the experimental protocol, sham and castrated mice displayed similar body weight. Both groups gained weight during the protocol development. However, the weight gain was higher in mice fed the HFD as compared to the CD-fed group. Castrated and Sham mice on the HFD showed similar body weight gain. Similarly, testosterone treatment did not modify weight gain in HFD- or CD-fed mice. Castration effectively reduced endogenous androgen levels, as evidenced by the undetectable levels of testosterone in castrated animals. Castrated mice fed the $\mathrm{CD}$ and treated with testosterone propionate $(5 \mathrm{mg} / \mathrm{kg}$ body weight) exhibited supraphysiological levels of testosterone, whereas castrated HFD-fed mice treated with the same dose of testosterone propionate ( $5 \mathrm{mg} / \mathrm{kg}$ body weight) exhibited testosterone levels similar to those observed in the sham group.

No differences in serum glucose were observed between sham and castrated mice fed the CD. However, HFD increased serum glucose in sham mice. Insulin and total cholesterol plasma levels were also increased in HFD-fed sham mice compared to CD-fed sham mice. Castration did not change increased serum glucose, insulin or total cholesterol levels induced by the HFD, but decreased triglyceride plasma levels in mice fed both the CD and HFD (Table 1). These results indicate that metabolic changes evoked by the HFD in young mice are not affected by either castration or supraphysiological levels of circulating testosterone.

\section{Castration Prevents Vascular Dysfunction in High Fat Diet-Fed Mice}

We then assessed the involvement of testosterone on vascular dysfunction in HFD-fed mice considering its independent association with cardiovascular complications. Castrated and sham-operated mice were fed the HFD and vascular function was evaluated. As shown in Figure 1A, no differences in SNPinduced vascular relaxation were observed between $C D$ sham and HFD sham mice. In contrast, HFD reduced ACh-induced vascular relaxation in sham mice in comparison with $\mathrm{CD}$-fed sham mice (Figure 1B). In mice fed the $C D$, there were no differences in ACh-induced vasodilatation between the sham and castrated groups. However, castration prevented HFD-induced vascular dysfunction (Figure 1C). Treatment of castrated mice maintained on the $\mathrm{CD}$ with testosterone propionate decreased ACh-induced vasodilation. The effects of castration on ACh vasodilation in HFD-fed mice, i.e., increased ACh vasodilatation, were lost upon testosterone propionate treatment (Figure 1D). Table 2 shows the maximum response and $p \mathrm{D}_{2}$ values.

\section{Castration Prevents Vascular Oxidative Stress in High Fat Diet-Fed Mice}

We next determined whether testosterone contributes to increased vascular ROS generation in mice on the HFD. As expected and already reported, HFD decreased plasma NOx (Figure 2A) and increased aortic TBARS levels (Figure 2B). Basal levels of ROS, determined by DHE fluorescence intensity (Figure 2C), were significantly increased in arteries from HFDfed sham mice. In addition, aortas from HFD sham mice exhibited increased generation of $\mathrm{O}_{2}{ }^{-}$(Figure 2D) and $\mathrm{H}_{2} \mathrm{O}_{2}$ (Figure 2E), determined by lucigenin chemiluminescence and amplex red, respectively. Castration prevented increased vascular ROS induced by HFD. No differences were observed in ROS generation between sham and castrated mice on the CD. Similarly to castration, tiron improved $\mathrm{ACh}$-induced vascular relaxation in HFD sham mice (Figure 2F). No additional effects were observed with the combination of tiron and castration, i.e., tiron did not further improve ACh vasodilation in HFD castrated mice (Figure 2G), indicating that both tiron and castration interfere with similar pathways. Table 3 shows the maximum response and $p \mathrm{D}_{2}$ values.

\section{Castration Prevents Downregulation of the Antioxidant System in High Fat Diet-Fed Mice}

Nuclear factor E2-related factor 2 signaling is a major regulator of cellular antioxidant systems. HFD increased vascular Keap1 protein expression (Figure 3A). In addition, HFD decreased nuclear accumulation of Nrf2 (Figure 3B), which was associated 
TABLE 1 | Body weight and biochemical profile in the experimental groups of mice.

\begin{tabular}{|c|c|c|c|c|c|c|}
\hline & CD Sham & CD Castrated & HFD Sham & HFD Castrated & CD Castrated + Testo & HFD Castrated + Testo \\
\hline Body weight (g) & $28.1 \pm 0.4$ & $26.7 \pm 0.6$ & $43.8 \pm 0.4^{*}$ & $41.7 \pm 0.8$ & $28.9 \pm 0.5$ & $45.1 \pm 0.3$ \\
\hline Testosterone (ng/mL) & $7.7 \pm 0.7$ & $0.9 \pm 0.4^{\star}$ & $6.4 \pm 0.8$ & $0.6 \pm 0.2^{\#}$ & $11.4 \pm 1.1^{*}$ & $7.8 \pm 1.2$ \\
\hline Glucose (mg/dL) & $79.8 \pm 3.1$ & $84.8 \pm 2.8$ & $184.3 \pm 5.9^{\star}$ & $141.4 \pm 10.7^{\#}$ & & \\
\hline Insulin (ng/mL) & $3.6 \pm 0.2$ & $3.4 \pm 0.3$ & $8.2 \pm 0.6^{\star}$ & $7.4 \pm 0.5$ & & \\
\hline Total Cholesterol (mg/dL) & $81.6 \pm 3.5$ & $80.1 \pm 3.2$ & $121.6 \pm 6.6^{*}$ & $129.1 \pm 6.5$ & & \\
\hline Triglyceride (mg/dL) & $67.1 \pm 5.4$ & $45.3 \pm 6.1^{\star}$ & $106.3 \pm 10.1^{*}$ & $57.3 \pm 8.5^{\#}$ & & \\
\hline
\end{tabular}

Values are expressed as mean \pm SEM $(n=10-12) . C D$, control diet; HFD, high fat diet. Two-way ANOVA: * $p<0.05$ vs. CD Sham; ${ }^{*} p<0.05$ vs. HFD Sham.
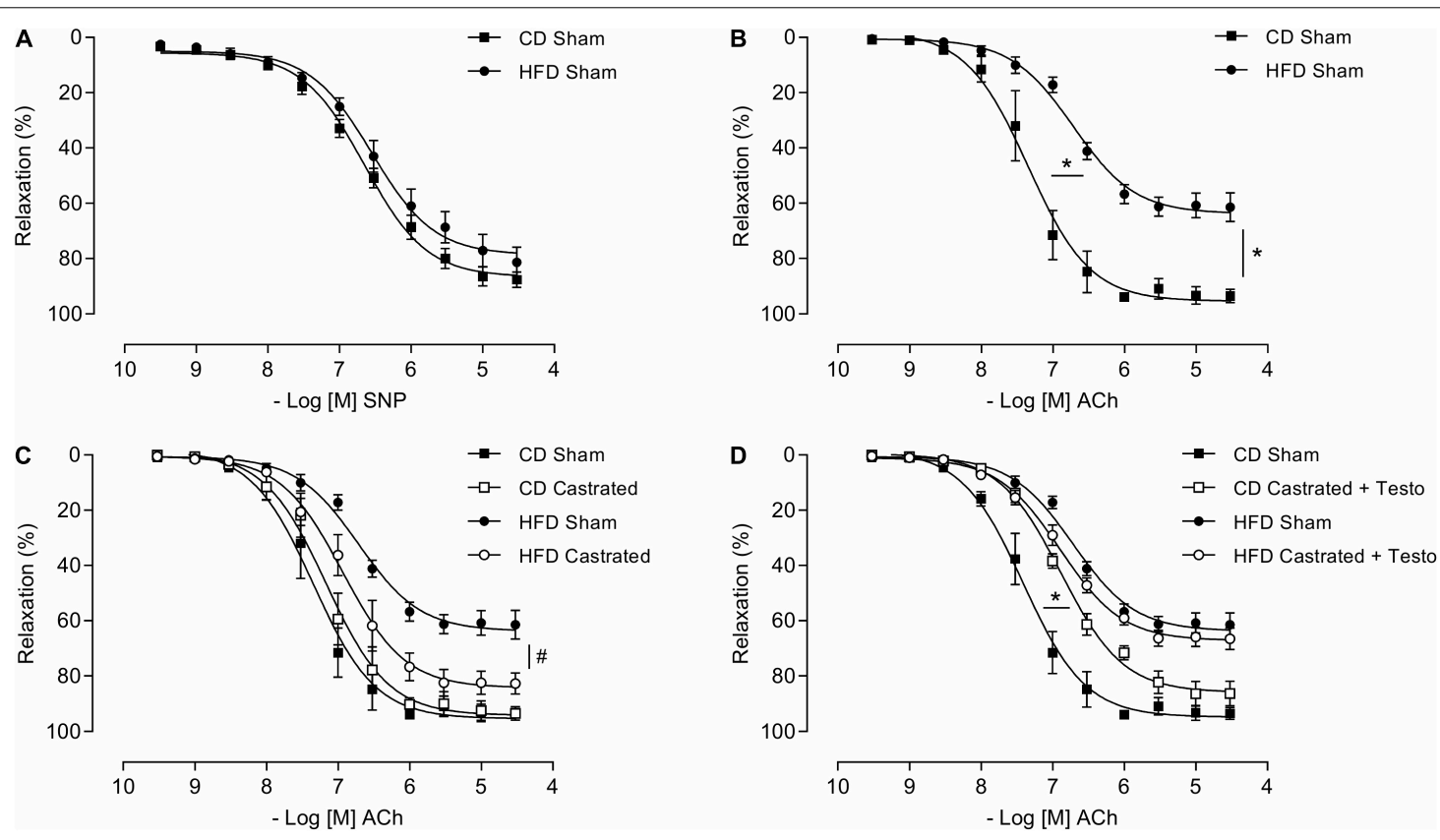

FIGURE 1 | Testosterone contributes to vascular dysfunction in high fat diet (HFD)-fed mice. Concentration-response curves to sodium nitroprusside - SNP (A) and acetylcholine (Ach) were performed in aortic rings isolated from control diet (CD) sham and HFD sham mice (B). ACh responses were also determined in aortic rings from castrated mice fed either a CD or HFD (CD castrated and HFD castrated, respectively) (C), and CD castrated and HFD castrated mice treated with testosterone propionate ( $5 \mathrm{mg} / \mathrm{Kg}$ for 15 days) (D). Data are expressed as mean \pm SEM ( $n=7$ in all groups). ${ }^{*} p<0.05$ vs. Sham; ${ }^{*} p<0.05$ vs. HFD Sham.

TABLE 2 | Emax and $p D_{2}$ values of sodium nitroprusside and acetylcholine-induced relaxation in thoracic aorta arteries.

\begin{tabular}{|c|c|c|c|c|c|c|c|c|}
\hline & $\begin{array}{l}\text { CD Sham } \\
\text { (SNP) }\end{array}$ & $\begin{array}{l}\text { HFD Sham } \\
\text { (SNP) }\end{array}$ & $\begin{array}{l}\text { CD Sham } \\
\text { (ACh) }\end{array}$ & $\begin{array}{l}\text { HFD Sham } \\
\text { (ACh) }\end{array}$ & $\begin{array}{c}\text { CD } \\
\text { Castrated } \\
(A C h)\end{array}$ & $\begin{array}{c}\text { HFD } \\
\text { Castrated } \\
(A C h)\end{array}$ & $\begin{array}{c}\text { CD } \\
\text { Castrated + Testo } \\
(A C h)\end{array}$ & $\begin{array}{l}\text { HFD Castrated }+ \text { Testo } \\
\text { (ACh) }\end{array}$ \\
\hline Emax & $86.6 \pm 1.6$ & $79.6 \pm 2.4$ & $95.3 \pm 2.7$ & $63.7 \pm 1.7^{\star}$ & $94.1 \pm 2.5$ & $84.2 \pm 2.4^{\#}$ & $85.8 \pm 1.6$ & $67.1 \pm 1.3$ \\
\hline$p D_{2}$ & $6.65 \pm 0.05$ & $6.54 \pm 0.08$ & $7.34 \pm 0.08$ & $6.71 \pm 0.07^{\star}$ & $7.16 \pm 0.07$ & $6.93 \pm 0.08$ & $6.88 \pm 0.05^{\star}$ & $6.89 \pm 0.05$ \\
\hline
\end{tabular}

Values are expressed as mean \pm SEM $(n=7) . C D$, control diet; HFD, high fat diet; SNP, sodium nitroprusside; ACh, acetylcholine. Two-way ANOVA: * $p<0.05$ vs. CD Sham; ${ }^{\#} p<0.05$ vs. HFD Sham.

with a decrease in mRNA expression of Nrf2-regulated enzymes, such as SOD-1 (Figure 3C), catalase (Figure 3D), heme oxygenase-1 (Figure 3E), peroxiredoxin (Figure 3F) as well as with decreased activity of the enzymes thioredoxin (Figure 3G), SOD (Figure 3H) and catalase (Figure 3I). These events were also prevented in castrated HFD-fed mice, indicating that Nrf2regulated redox balance in the vasculature of obese mice is modulated by testosterone. No differences were observed in Nrf2 antioxidant system between sham and castrated mice on the CD.

\section{Castration Prevents Vascular Dysfunction in High Fat Diet-Fed Mice by Mechanisms That Involve Nuclear Factor E2-Related Factor 2 Activation}

Activation of the Nrf2 system by bardoxolone improved ACh-induced vascular relaxation in HFD-fed sham mice (Figure 4A). The effects of bardoxolone and castration on ACh vasodilation were similar in HFD-fed mice (Figure 4B), 

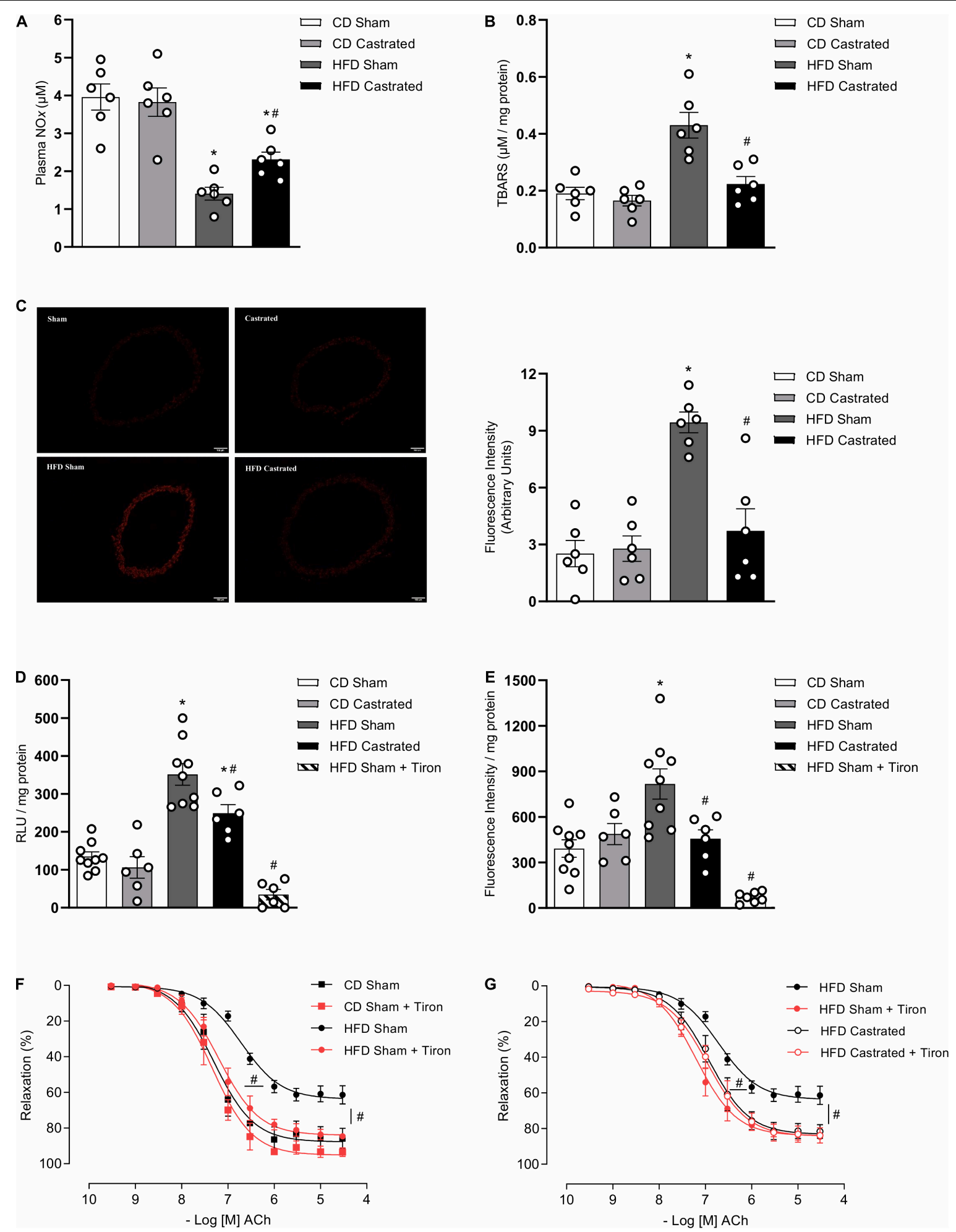

FIGURE 2 | Testosterone contributes to vascular oxidative stress in high fat diet (HFD)-fed mice. Plasma NOx [(A) $n=6$ for each experimental group], TBARS [(B) $n=6$ for each experimental group], reactive oxygen species generation - measured by DHE [(C) $n=6$ for each experimental group], superoxide anion generation - measured by lucigenin [(D) $n=6$ or 9 for each experimental group], and hydrogen peroxide levels - determined by amplex red [(E) $n=6$ or 9 for each experimental group] were evaluated in aortas isolated from mice of the different experimental groups. Concentration-response curves to acetylcholine (Ach) were performed in aortic rings isolated from control diet (CD) sham, HFD sham, and HFD castrated mice in the presence of Tiron (10 ${ }^{-4}$ M) $[(\mathbf{F}, \mathbf{G}) n=7$ in all groups]. Data are expressed as mean \pm SEM. ${ }^{\star} p<0.05$ vs. CD Sham; ${ }^{\#} p<0.05$ vs. HFD Sham. 
TABLE 3 | Emax and $p D_{2}$ values of acetylcholine-induced relaxation in thoracic aorta arteries incubated with vehicle or Tiron.

\begin{tabular}{|c|c|c|c|c|c|c|}
\hline & CD Sham & CD Sham + Tiron & HFD Sham & HFD Sham + Tiron & HFD Castrated & HFD Castrated + Tiron \\
\hline Emax & $87.7 \pm 3.1$ & $95.1 \pm 2.5$ & $63.7 \pm 1.7$ & $83.9 \pm 1.9^{\#}$ & $83.2 \pm 2.3^{\#}$ & $84.2 \pm 2.2$ \\
\hline$p D_{2}$ & $7.30 \pm 0.10$ & $7.33 \pm 0.08$ & $6.71 \pm 0.07$ & $7.19 \pm 0.06^{\#}$ & $6.92 \pm 0.08^{\#}$ & $6.95 \pm 0.07$ \\
\hline
\end{tabular}

Values are expressed as mean \pm SEM $(n=7)$. CD, control diet; HFD, high fat diet. Two-way ANOVA: \# $p<0.05$ vs. HFD Sham.
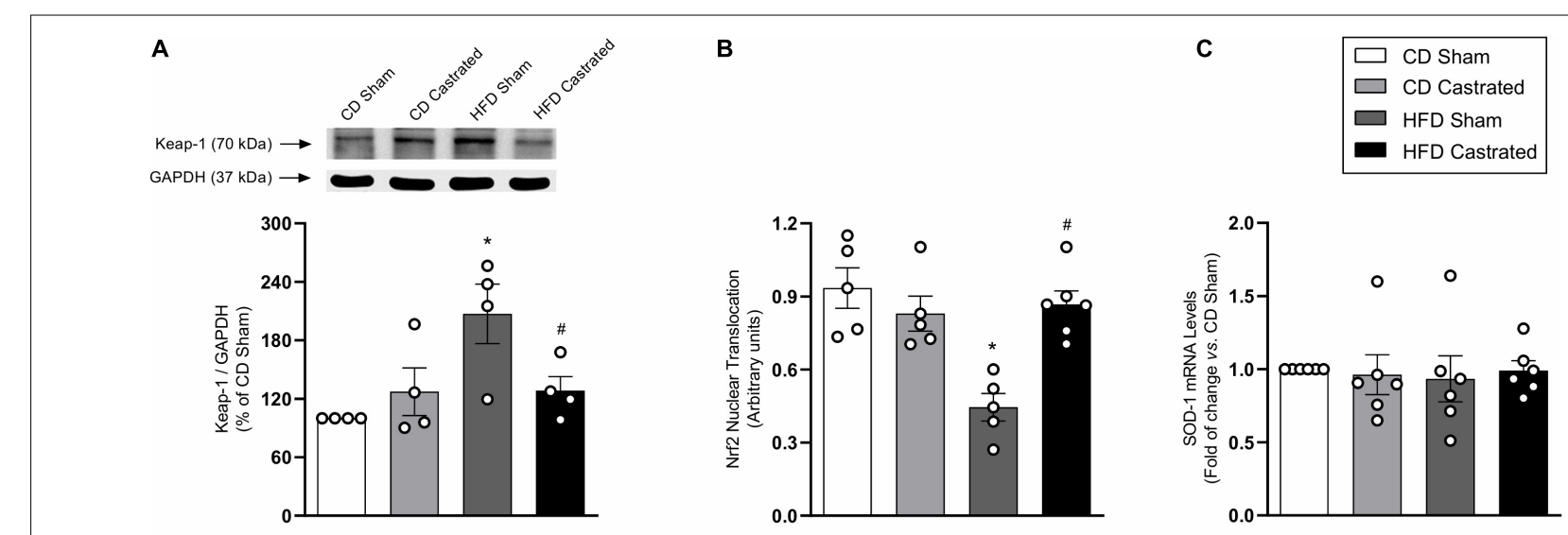

D

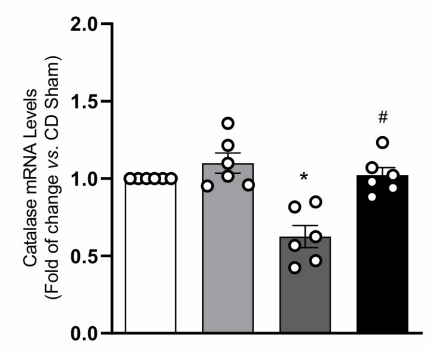

G

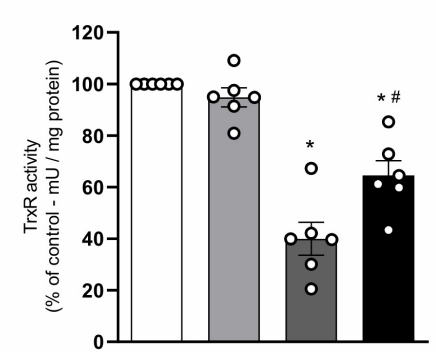

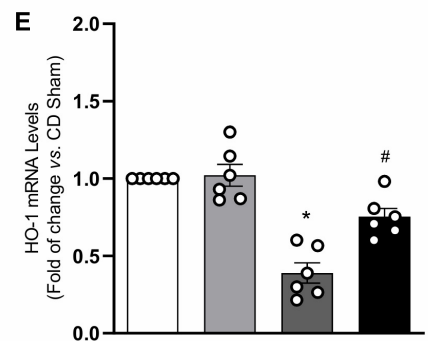
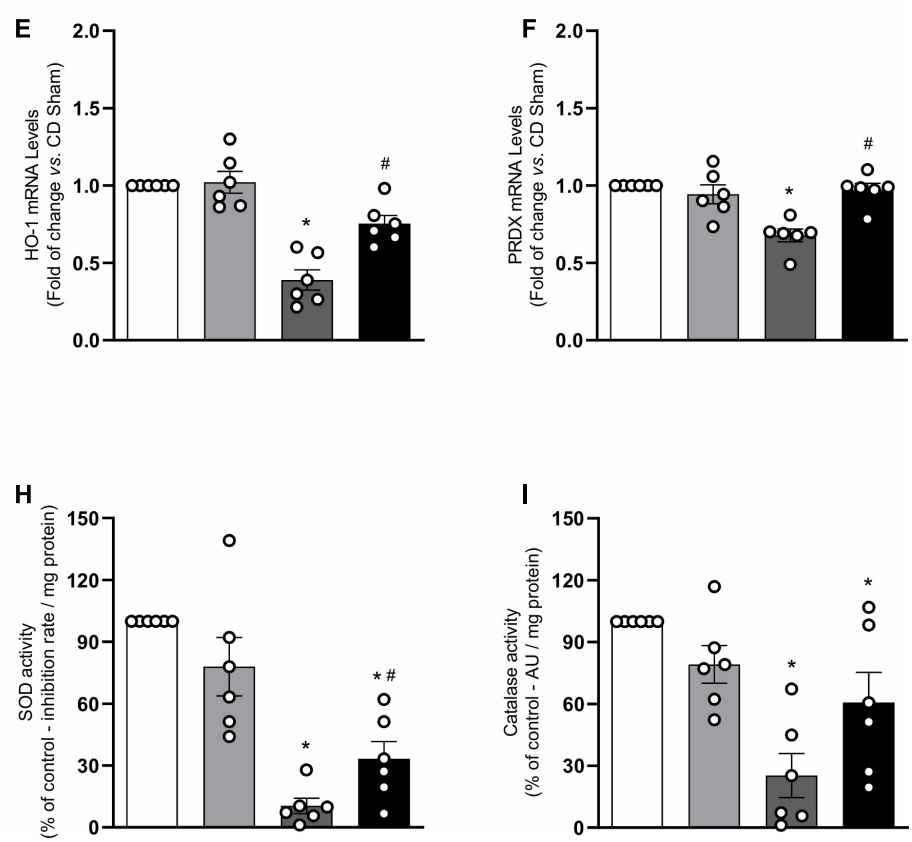

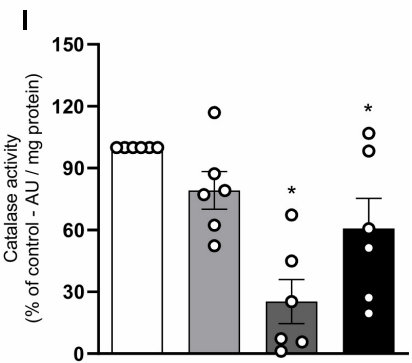

FIGURE 3 | Testosterone contributes to downregulation of the nuclear factor E2-related factor 2 (Nrf2) antioxidant system in high fat diet (HFD)-fed mice. The experiments were performed in aortas isolated from the various experimental groups. Total levels of Keap-1 [(A) $n=4$ for each experimental group]. Nuclear accumulation of Nrf2 [(B) $n=5$ or 6 for each experimental group]. mRNA expression of genes regulated by Nrf2: SOD-1 [(C) $n=6$ for each experimental group], catalase [(D) $n=6$ for each experimental group], heme oxygenase-1 [(E) $n=6$ for each experimental group] and peroxiredoxin-1 [(F) $n=6$ for each experimental group]. Activity of antioxidant enzymes thioredoxin reductase [(G) $n=6$ for each experimental group], SOD [(H) $n=6$ for each experimental group] and catalase $\left[(\mathbf{I}) n=6\right.$ for each experimental group]. Data are expressed as mean \pm SEM. ${ }^{*} p<0.05$ vs. CD Sham; ${ }^{\#} p<0.05$ vs. HFD Sham.

with no additional effects being observed in arteries from castrated mice incubated with bardoxolone. Bardoxolone did not change vascular reactivity in sham or castrated mice fed the CD. Bardoxolone increased nuclear accumulation of Nrf2 in vessels from HFD-fed sham mice (Figure 4C) and decreased HFD-induced vascular ROS generation (Figure 4D). Notably, no synergism was observed between the effects of bardoxolone and castration. In addition, bardoxolone improved catalase and heme 


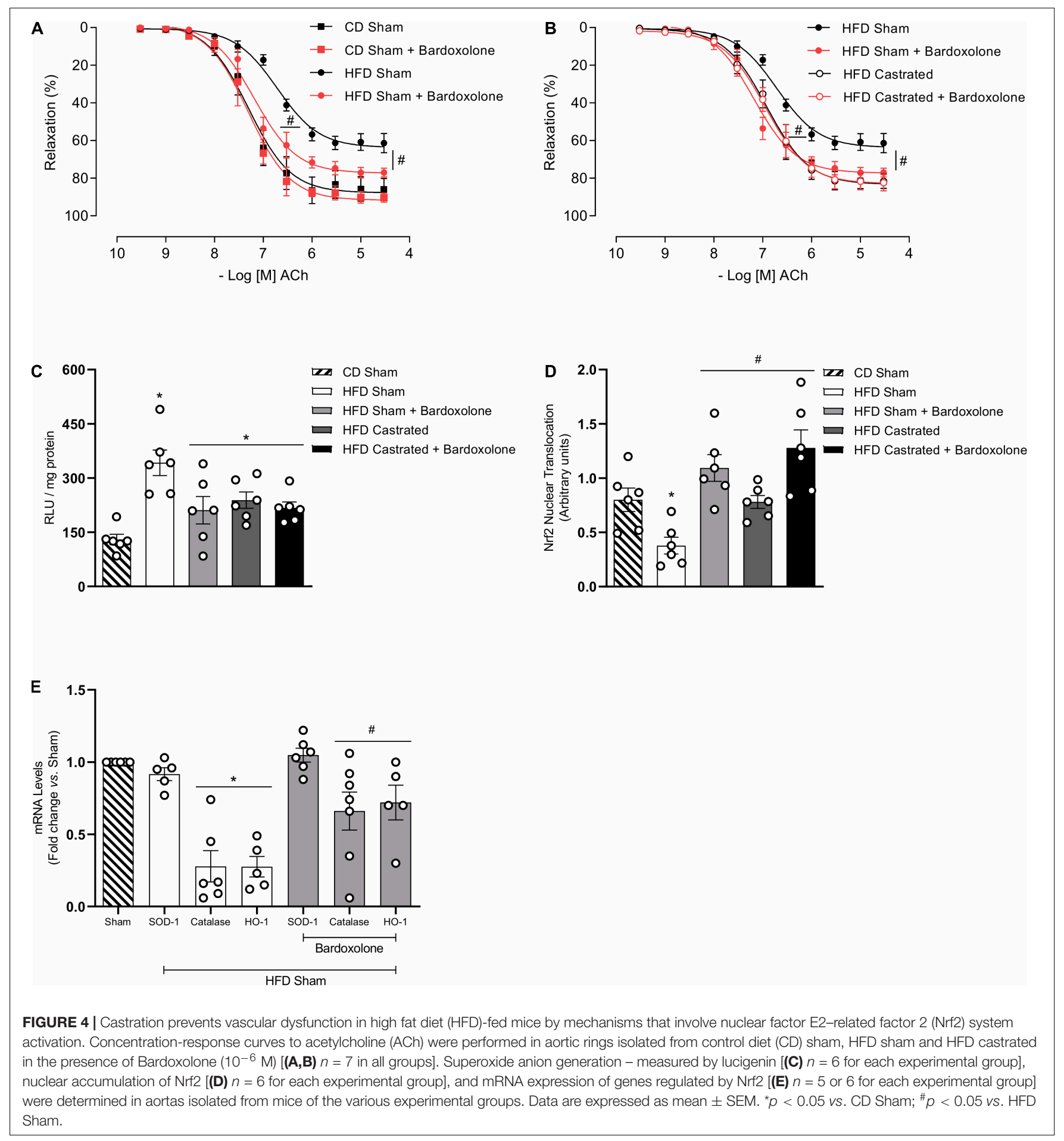

TABLE 4 | Emax and $p D_{2}$ values of acetylcholine-induced relaxation in thoracic aorta arteries incubated with vehicle or Bardoxolone.

\begin{tabular}{lcccccc}
\hline & CD Sham & CD Sham + Bardoxolone & HFD Sham & HFD Sham + Bardoxolone & HFD Castrated & HFD Castrated + Bardoxolone \\
\hline Emax & $87.7 \pm 3.1$ & $91.7 \pm 2.2$ & $63.7 \pm 1.7$ & $77.2 \pm 1.8^{\#}$ & $83.2 \pm 2.3^{\#}$ & $82.8 \pm 2.3$ \\
$\mathrm{pD}_{2}$ & $7.30 \pm 0.10$ & $7.31 \pm 0.06$ & $6.71 \pm 0.07$ & $7.18 \pm 0.07^{\#}$ & $6.92 \pm 0.08^{\#}$ & $6.94 \pm 0.06$ \\
\hline
\end{tabular}

Values are expressed as mean \pm SEM $(n=7)$. CD, control diet; HFD, high fat diet. Two-way ANOVA: ${ }^{p}<0.05$ vs. HFD Sham. 
oxygenase-1 mRNA expression (Figure 4E). Table 4 shows the maximum response and $p \mathrm{D}_{2}$ values.

\section{Castration Prevents Increased NADPH Oxidase Expression in High Fat Diet-Fed Mice}

NADPH oxidase is the main source of free radicals in the vasculature. HFD increased NOX1 expression in aortas, which was prevented in castrated HFD-fed mice (Figure 5A). No difference was observed in the antioxidant system between sham and castrated mice fed the $\mathrm{CD}$. In addition, no difference was observed in NOX4 (Figure 5B) expression among the different experimental groups.

\section{NOX-1 Contribution to Testosterone-Induced Reactive Oxygen Species Generation and Endothelial Dysfunction}

Considering that testosterone modulates endothelial cell function as well as oxidative and inflammatory processes in endothelial cells, we further determined molecular mechanisms involved in testosterone-mediated endothelial dysfunction, by using EA.hy926 cells. Testosterone induced a time-dependent ROS generation in EA.hy926 cells (Figure 6A), with maximum generation occurring at $2 \mathrm{~h}$. In addition, testosterone increased nuclear accumulation of Nrf2 from $30 \mathrm{~min}$, but this increase was reduced after $3 \mathrm{~h}$ of stimulation with testosterone (Figure 6B). Incubation of EA.hy926 cells with bardoxolone prevented ROS generation (Figure 6C). Testosterone-induced ROS generation at 3 and $6 \mathrm{~h}$ was prevented by ML171, a NOX1 inhibitor (Figure 6D). To investigate the possible mechanisms (genomic and non-genomic) whereby testosterone induces ROS production at 3 and $6 \mathrm{~h}$, ROS generation was determined in the presence of flutamide and actinomycin D. Pre-incubation with flutamide prevented testosterone-induced ROS generation at $3 \mathrm{~h}$, but not at $6 \mathrm{~h}$. On the other hand, incubation with actinomycin $\mathrm{D}$ prevented testosterone-induced ROS generation at $6 \mathrm{~h}$, but not at $3 \mathrm{~h}$ (Figure 6E). Actinomycin D prevented the decrease in Nrf2 activity induced by testosterone. Testosterone-induced decrease in Nrf2 activity was not observed in the presence of flutamide (Figure 6F).

\section{DISCUSSION}

The present study shows that testosterone plays a critical role in the progressive vascular oxidative damage caused by obesogenic diets in young male mice, mediating a set of changes that are very similar to those previously described in adult males. Accordingly, we demonstrated that testosterone, via androgen receptors, induces NOX1-dependent oxidative stress and negatively impacts Nrf2/Keap1 signaling, one of the main protective responses to oxidative stress.

It is extensively known that testosterone does not contribute exclusively to the development of the male reproductive system and sexual maturation. Clinical and experimental evidence shows that testosterone also modulates cardiovascular homeostasis and produces important cardiac and vascular effects in physiopathological conditions, including obesity (Torres et al., 2007; Wang et al., 2011; Fui et al., 2014). Adult wistar rats fed a sucrose-rich diet exhibit increased vascular contractions to noradrenaline and this increase is prevented by castration (Vasudevan et al., 2006; Perez et al., 2009). In line with these observations, the present study shows that obesity in young male mice impairs vascular function, as evidenced by the decrease in acetylcholine-mediated vasodilation. Castration of these young animals also prevented obesity-associated endothelial dysfunction. The findings that testosterone replacement in castrated young obese mice impairs vasodilation, confirms that testosterone negatively influences vascular tone during obesity development in young mice.

Although the mechanisms by which obesity causes vascular dysfunction in adult are still not completely known, it is clear that this condition is associated with vascular oxidative stress, increased vasoconstriction and decreased vasodilation (Stapleton et al., 2008). Accordingly, our data clearly show that obesity induced by a high fat diet in young mice also increases free radical's generation in the vasculature, increases lipid peroxidation and reduces NO bioavailability. In addition, castration prevents oxidative stress and improves endothelial function in arteries of obese mice, indicating that testosterone is pro-oxidant and contributes to vascular dysfunction in young obesity. This is in agreement with previous studies demonstrating that, in adult experimental models, testosterone increases ROS generation in VSMC via NADPH oxidase- (Chignalia et al., 2012) and mitochondrial respiratory chain-dependent mechanisms (Lopes et al., 2014).

Free radical's levels are controlled by intracellular defense mechanisms that rely on the expression and activity of antioxidant enzymes. The Nrf2 system is essential for redox balance in the cardiovascular system. Nrf2 activation has vasoprotective effects via reduction of ROS and increased bioavailability of NO (Mann et al., 2007; Lopes et al., 2015). In adult obesity, the Nrf2 system is downregulated, since Nrf2 translocation to the nucleus is decreased in arteries of obese mice. In addition, expression of Keap-1, which negatively regulates Nrf2 degradation, maintaining Nrf2 in the cytosol, was increased in arteries from obese mice. Increased Keap-1 expression may account for the decreased vascular nuclear translocation of Nrf2. This is supported by studies showing decreased activity of Nrf2 in adipose tissue (Zamora-Mendoza et al., 2018) and renal cells of obese mice (Chin et al., 2013). In addition, mesenteric arteries of obese animals that do not express the leptin receptor exhibit decreased Nrf2 activity, which contributes to oxidative stress and increased vasoconstriction. Treatment of these animals with the Nrf2 activator L-sulforaphane reduces ROS and improves vascular function (Alves-Lopes et al., 2016). These data further support our results showing that decreased Nrf2 activity impairs vascular function and that activation of the Nrf2 system by bardoxolone prevents high fat diet-induced vascular dysfunction in young obese mice.

Castration increases Nrf2 activity and the expression and activity of antioxidant enzymes in arteries of obese mice, clearly 


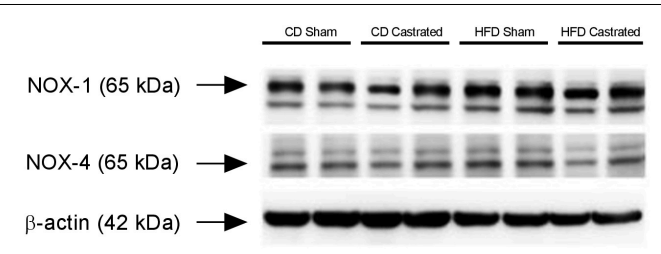

A

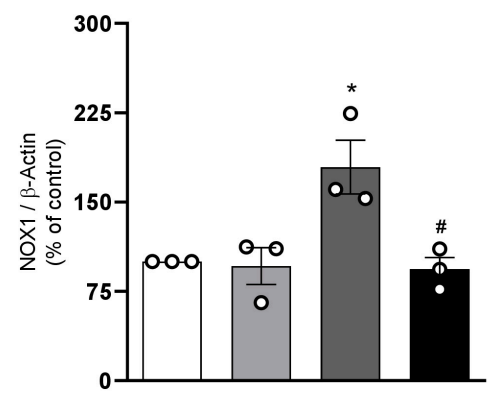

B

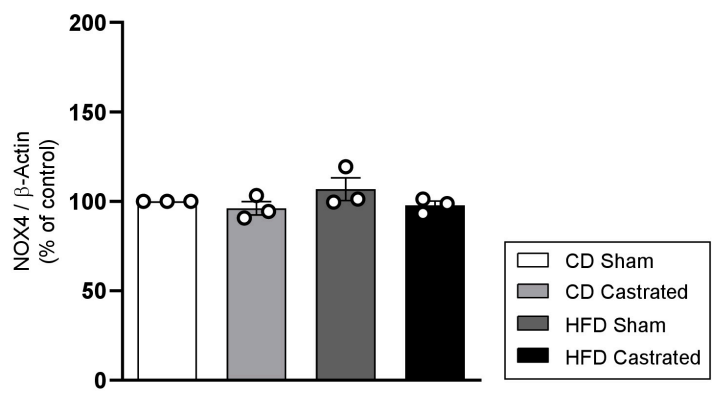

FIGURE 5 | Testosterone contributes to increased vascular NOX1 expression in high fat diet (HFD)-fed mice. The experiments were performed in aortas isolated from mice of the different experimental groups. Total levels of NOX1 (A) and NOX4 (B), determined by western blot, were normalized by $\beta$-actin expression. Data are expressed as mean \pm SEM ( $n=3$ in all groups). ${ }^{*} p<0.05$ vs. CD Sham; ${ }^{*} p<0.05$ vs. HFD Sham.

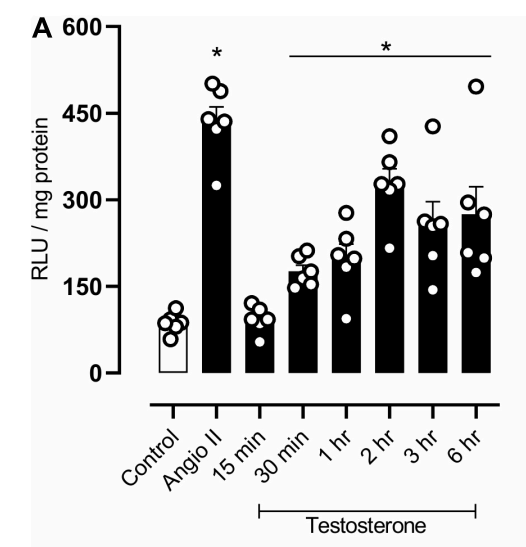

D

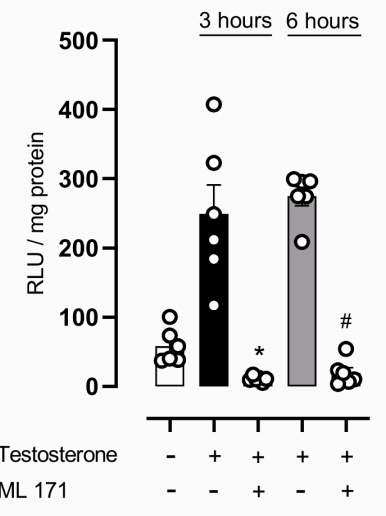

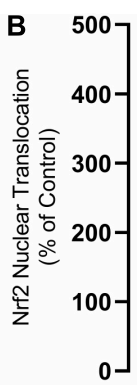
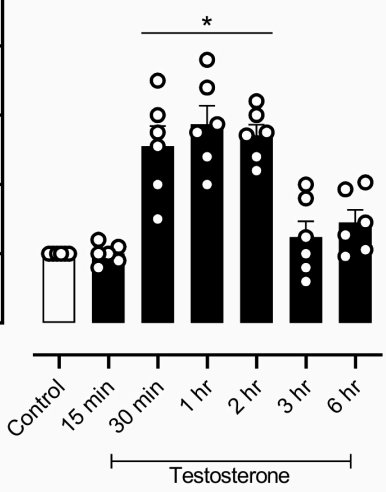

E

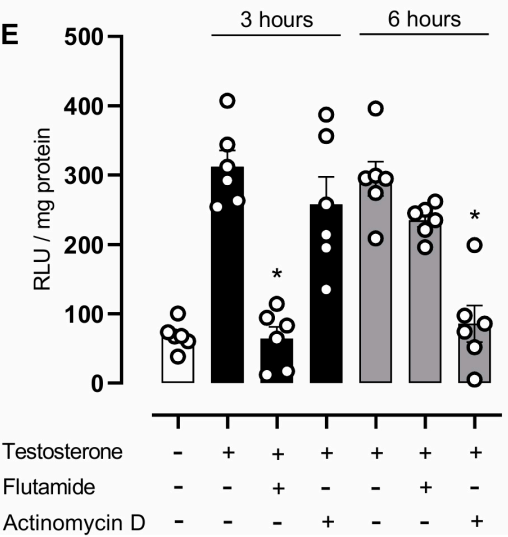

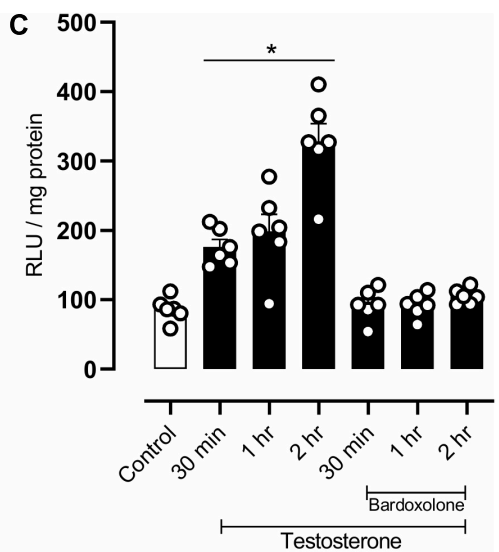
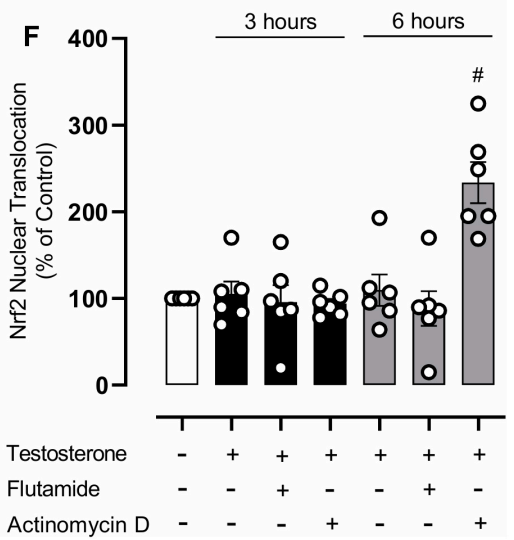

6 hours

FIGURE 6 | Testosterone induces a biphasic increase in reactive oxygen species (ROS) generation by mechanisms that involves NOX1 activation and downregulation of nuclear factor E2-related factor 2 (Nrf2) activity in endothelial cells. Superoxide anion generation was measured by lucigenin [(A,C-E) $n=6$ or 7 for each experimental group] and nuclear accumulation of $\mathrm{Nrf2}\left[(\mathbf{B}, \mathbf{F}) n=6\right.$ for each experimental group]. Data are expressed as mean \pm SEM. ${ }^{*} p<0.05$ vs. Control; ${ }^{*} p<0.05$ vs. Testosterone. 
indicating that testosterone negatively regulates Nrf2 signaling during transition from early to middle adulthood, when most body mass gain occurs. Considering that fat deposition early in life accounts for increased cardiovascular risk in adulthood, the effects of testosterone, demonstrated in our study, may represent an important mechanism mediating this process.

A link between Nrf2 and testosterone has been previously reported in adult experimental models. Nrf2 knockout mice exhibit increased ROS generation and fluctuations in plasma testosterone levels due to Leydig cell deficiency (Chen et al., 2015). Recent data from our group showed that hyperglycemia, a condition found in diabetes mellitus, reduces Nrf2 activity, increases the activity of pro-oxidant enzymes and ROS generation, leading to vascular (pudendal arteries) dysfunction. Considering that this vascular bed is highly responsive to the actions of testosterone (Alves-Lopes et al., 2016), this reinforces the hypothesis that blood vessels are modulated by redox mechanisms sensitive to testosterone even during fat accumulation early in life.

Arteries of young obese mice exhibited increased expression of NOX1, a $\mathrm{NAD}(\mathrm{P}) \mathrm{H}$ oxidase isoform, and, interestingly, castration prevented this increase. Accordingly, it has been reported that testosterone increases the expression of NADPH oxidase subunits in VSMC, increasing ROS generation and cell migration (Chignalia et al., 2012). We sought to further explore the mechanisms activated by testosterone that culminate in endothelial dysfunction and subsequent vascular dysfunction. In cultured endothelial cells, testosterone increased ROS generation in a time-dependent manner; initially by non-genomic actions and activation of androgen receptors and later by genomic effects. Testosterone also decreased Nrf2 activity by mechanisms that rely on gene transcription. Similar to the present findings, it was reported that ROS generation induced by testosterone depends on early-activated genomic mechanisms and also on latelyactivated non-genomic mechanisms (Chignalia et al., 2015).

In conclusion, the present study demonstrated that testosterone downregulates the Nrf2 antioxidant system, favoring NOX1 activity, ROS accumulation and vascular dysfunction in HFD-fed young obese mice. These findings indicate that testosterone constitutes an important mediator of the progressive vascular oxidative damage caused by obesogenic diets in young

\section{REFERENCES}

Alves, J. V., da Costa, R. M., Pereira, C. A., Fedoce, A. G., Silva, C. A. A., Carneiro, F. S., et al. (2020). Supraphysiological levels of testosterone induce vascular dysfunction via activation of the NLRP3 inflammasome. Front. Immunol. 11:1647. doi: 10.3389/fimmu.2020.01647

Alves-Lopes, R., Neves, K. B., Montezano, A. C., Harvey, A., Carneiro, F. S., Touyz, R. M., et al. (2016). Internal pudental artery dysfunction in diabetes mellitus is mediated by NOX1-Derived ROS-, Nrf2-, and Rho kinase-dependent mechanisms. Hypertension 68, 1056-1064. doi: 10.1161/ HYPERTENSIONAHA.116.07518

Andersson, C., and Vasan, R. S. (2018). Epidemiology of cardiovascular disease in young individuals. Nat. Rev. Cardiol. 15, 230-240. doi: 10.1038/nrcardio.2017. 154

Betteridge, D. J. (2000). What is oxidative stress? Metabolism 49, 3-8. doi: 10.1016/ s0026-0495(00)80077-3 male mice, favoring a vascular oxidative status that is similar to that observed in adult obesity.

\section{DATA AVAILABILITY STATEMENT}

The raw data supporting the conclusions of this article will be made available by the authors, without undue reservation.

\section{ETHICS STATEMENT}

The animal study was reviewed and approved by Ethics Committee on Animal Use (CEUA) of the University of São Paulo, Ribeirão Preto, Brazil (Protocol no 206/2016).

\section{AUTHOR CONTRIBUTIONS}

RC, NL, FC, and RT participated in the design of the study, provided the reagents and analytical tools, and wrote the manuscript. RC, RA-L, JA, CS, and FM performed the experiments and data analysis. All authors contributed to the article and approved the submitted version.

\section{FUNDING}

This research received funding from the São Paulo Research Foundation (FAPESP, grant no. 2013/08216-2, Center for Research in Inflammatory Diseases - CRID) and Conselho Nacional de Desenvolvimento Científico e Tecnológico (CNPq), Grant No. 433898/2018-6.

\section{SUPPLEMENTARY MATERIAL}

The Supplementary Material for this article can be found online at: https://www.frontiersin.org/articles/10.3389/fphys. 2022.837603/full\#supplementary-material

Bhasin, S., and Herbst, K. (2003). Testosterone and atherosclerosis progression in men. Diabet. Care 26, 1929-1931. doi: 10.2337/diacare.26.6. 1929

Bradford, M. M. (1976). A rapid and sensitive method for the quantitation of microgram quantities of protein utilizing the principle of proteindye binding. Anal. Biochem. 72, 248-254. doi: 10.1006/abio.1976. 9999

Caprio, S., Santoro, N., and Weiss, R. (2020). Childhood obesity and the associated rise in cardiometabolic complications. Nat. Metab. 2, 223-232. doi: 10.1038/ s42255-020-0183-Z

Chen, H., Jin, S., Guo, J., Kombairaju, P., Biswal, S., and Zirkin, B. R. (2015). Knockout of the transcription factor Nrf2: effects on testosterone production by aging mouse Leydig cells. Mol. Cell. Endocrinol. 409, 113-120. doi: 10.1016/ j.mce.2015.03.013

Chignalia, A. Z., Oliveira, M. A., Debbas, V., Dull, R. O., Laurindo, F. R., Touyz, R. M., et al. (2015). Testosterone induces leucocyte migration by NADPH 
oxidase-driven ROS-and COX2-dependent mechanisms. Clin. Sci. 129, 39-48. doi: 10.1042/CS20140548

Chignalia, A. Z., Schuldt, E. Z., Camargo, L. L., Montezano, A. C., Callera, G. E., Laurindo, F. R., et al. (2012). Testosterone induces vascular smooth muscle cell migration by NADPH oxidase and c-Src-dependent pathways. Hypertension 59, 1263-1271. doi: 10.1161/HYPERTENSIONAHA.111.18 0620

Chin, M., Lee, C. Y. I., Chuang, J. C., Bumeister, R., Wigley, W. C., Sonis, S. T., et al. (2013). Bardoxolone methyl analogs RTA 405 and dh404 are well tolerated and exhibit efficacy in rodent models of Type 2 diabetes and obesity. Am. J. Physiol. Renal Physiol. 304, F1438-F1446. doi: 10.1152/ajprenal.00387. 2012

CONCEA-MCT (2013). Ministério da Ciência, Tecnologia e Inovação Conselho Nacional de Controle de Experimentação Animal. Diretriz Brasileira para o Cuidado e a Utilização de Animais para Fins Científicos e Didáticos - DBCA. Brazilian Government. Available online at: https://pages.cnpem.br/ceua/wpcontent/uploads/sites/56/2015/06/DBCA.pdf

Costa, R. M., Filgueira, F. P., Tostes, R. C., Carvalho, M. H. C., Akamine, E. H., and Lobato, N. S. (2016). $\mathrm{H} 2 \mathrm{O} 2$ generated from mitochondrial electron transport chain in thoracic perivascular adipose tissue is crucial for modulation of vascular smooth muscle contraction. Vasc. Pharmacol. 84, 28-37. doi: 10.1016/ j.vph.2016.05.008

Costa, R. M., Neves, K. B., Tostes, R. C., and Lobato, N. S. (2018). Perivascular adipose tissue as a relevant fat depot for cardiovascular risk in obesity. Front. Physiol. 9:253. doi: 10.3389/fphys.2018.00253

Csige, I., Ujvárosy, D., Szabó, Z., Lõrincz, I., Paragh, G., Harangi, M., et al. (2018). The impact of obesity on the cardiovascular system. J. Diabetes Res. 2018:3407306.

Cuadrado, A., Rojo, A. I, Wells, G., Hayes, J. D., Cousin, S. P., Rumsey, W. L., et al. (2019). Therapeutic targeting of the NRF2 and KEAP1 partnership in chronic diseases. Nat. Rev. Drug Discov. 18, 295-317. doi: 10.1038/s41573-018-0 008-x

da Costa, R. M., Fais, R. S., Dechandt, C. R., Louzada-Junior, P., Alberici, L. C., Lobato, N. S., et al. (2017). Increased mitochondrial ROS generation mediates the loss of the anti-contractile effects of perivascular adipose tissue in highfat diet obese mice. Br. J. Pharmacol. 174, 3527-3541. doi: 10.1111/bph. 13687

da Costa, R. M., Rodrigues, D., Pereira, C. A., Silva, J. F., Alves, J. V., Lobato, N. S., et al. (2019). Nrf2 as a potential mediator of cardiovascular risk in metabolic diseases. Front. Pharmacol. 10:382. doi: 10.3389/fphar.2019.0 0382

da Costa, R. M., Silva, J. F. D., Alves, J. V., Dias, T. B., Rassi, D. M., Garcia, L. V., et al. (2018). Increased O-GlcNAcylation of endothelial nitric oxide synthase compromises the anti-contractile properties of perivascular adipose tissue in metabolic syndrome. Front. Physiol. 9:341. doi: 10.3389/fphys.2018.0 0341

Druet, C., Stettler, N., Sharp, S., Simmons, R. K., Cooper, C., Smith, G. D., et al. (2012). Prediction of childhood obesity by infancy weight gain: an individuallevel meta-analysis. Paediatr. Perinat. Epidemiol. 26, 19-26. doi: 10.1111/j.13653016.2011.01213.x

Fui, M. N. T., Dupuis, P., and Grossmann, M. (2014). Lowered testosterone in male obesity: mechanisms, morbidity and management. Asian J. Androl. 16:223. doi: 10.4103/1008-682X.122365

Furukawa, S., Fujita, T., Shimabukuro, M., Iwaki, M., Yamada, Y., Nakajima, Y., et al. (2004). Increased oxidative stress in obesity and its impact on metabolic syndrome. J. Clin. Investig. 114, 1752-1761. doi: 10.1172/JCI21625

Hill, J. O. (2006). Understanding and addressing the epidemic of obesity: an energy balance perspective. Endocr. Rev. 27, 750-761. doi: 10.1210/er.20060032

Horie, Y., Suzuki, T., Inoue, J., Iso, T., Wells, G., Moore, T. W., et al. (2021). Molecular basis for the disruption of Keap1-Nrf2 interaction via Hinge \& Latch mechanism. Commun. Biol. 4:576. doi: 10.1038/s42003-021-02100-6

Jiang, S. Z., Lu, W., Zong, X. F., Ruan, H. Y., and Liu, Y. (2016). Obesity and hypertension. Exp. Ther. Med. 12, 2395-2399.

Kahn, S. E., Hull, R. L., and Utzschneider, K. M. (2006). Mechanisms linking obesity to insulin resistance and type 2 diabetes. Nature 444, 840-846. doi: 10.1038/nature05482
Kawagishi, H., and Finkel, T. (2014). Unraveling the truth about antioxidants: ROS and disease: finding the right balance. Nat. Med. 20, 711-713. doi: 10.1038/nm. 3625

Kelly, D. M., and Jones, T. H. (2013). Testosterone: a metabolic hormone in health and disease. J. Endocrinol. 217, R25-R45. doi: 10.1530/JOE-12-0455

Kloner, R. A., Carson, C., Dobs, A., Kopecky, S., and Mohler, E. R. (2016). Testosterone and cardiovascular disease. J. Am. Coll. Cardiol. 67, 545-557.

Krauss, R. M., Winston, M., Fletcher, B. J., and Grundy, S. M. (1998). Obesity: impact on cardiovascular disease. Circulation 98, 1472-1476.

Lopes, R. A. M., Neves, K. B., Carneiro, F. S., and Tostes, R. (2012). Testosterone and vascular function in aging. Front. Physiol. 3:89. doi: 10.3389/fphys.2012. 00089

Lopes, R. A. M., Neves, K. B., Pestana, C. R., Queiroz, A. L., Zanotto, C. Z., Chignalia, A. Z., et al. (2014). Testosterone induces apoptosis in vascular smooth muscle cells via extrinsic apoptotic pathway with mitochondria-generated reactive oxygen species involvement. Am. J. Physiol. Heart Circ. Physiol. 306, H1485-H1494. doi: 10.1152/ajpheart.00809. 2013

Lopes, R. A., Neves, K. B., Tostes, R. C., Montezano, A. C., and Touyz, R. M. (2015). Downregulation of nuclear factor erythroid 2-related factor and associated antioxidant genes contributes to redox-sensitive vascular dysfunction in hypertension. Hypertension 66, 1240-1250. doi: 10.1161/ HYPERTENSIONAHA.115.06163

Mancini, M., Pecori Giraldi, F., Andreassi, A., Mantellassi, G., Salvioni, M., Berra, C. C., et al. (2021). Obesity is strongly associated with low testosterone and reduced penis growth during development. J. Clin. Endocrinol. Metab. 106, 3151-3159. doi: 10.1210/clinem/dgab535

Mann, G. E., Rowlands, D. J., Li, F. Y., de Winter, P., and Siow, R. C. (2007). Activation of endothelial nitric oxide synthase by dietary isoflavones: role of $\mathrm{NO}$ in Nrf2-mediated antioxidant gene expression. Cardiovasc. Res. 75, 261-274. doi: 10.1016/j.cardiores.2007.04.004

Monteiro, P. O. A., and Victora, C. G. (2005). Rapid growth in infancy and childhood and obesity in later life-a systematic review. Obes. Rev. 6, 143-154. doi: 10.1111/j.1467-789X.2005.00183.x

Nadeau, K. J., Maahs, D. M., Daniels, S. R., and Eckel, R. H. (2011). Childhood obesity and cardiovascular disease: links and prevention strategies. Nat. Rev. Cardiol. 8, 513-525. doi: 10.1038/nrcardio.2011.86

Nguyen, T., Nioi, P., and Pickett, C. B. (2009). The Nrf2-antioxidant response element signaling pathway and its activation by oxidative stress. J. Biol. Chem. 284, 13291-13295. doi: 10.1074/jbc.r900010200

Ong, K. K., and Loos, R. J. (2006). Rapid infancy weight gain and subsequent obesity: systematic reviews and hopeful suggestions. Acta Paediatr. 95, 904-908. doi: 10.1080/08035250600719754

Perez, I., El Hafidi, M., Carvajal, K., and Baños, G. (2009). Castration modifies aortic vasoreactivity and serum fatty acids in a sucrose-fed rat model of metabolic syndrome. Heart Vessels 24:147. doi: 10.1007/s00380-008-1098- $\mathrm{x}$

Puttabyatappa, Y., Stallone, J. N., Ergul, A., El-Remessy, A. B., Kumar, S., Black, S., et al. (2013). Peroxynitrite mediates testosterone-induced vasodilation of microvascular resistance vessels. J. Pharmacol. Exp. Ther. 345, 7-14. doi: 10. 1124/jpet.112.201947

Rodrigues, D., Costa, T. J., Silva, J. F., Neto, J. T. D. O., Alves, J. V., Fedoce, A. G., et al. (2021). Aldosterone negatively regulates Nrf2 activity: an additional mechanism contributing to oxidative stress and vascular dysfunction by aldosterone. Int. J. Mol. Sci. 22:6154. doi: 10.3390/ijms22116154

Stapleton, P. A., James, M. E., Goodwill, A. G., and Frisbee, J. C. (2008). Obesity and vascular dysfunction. Pathophysiology 15, 79-89.

Stettler, N., and Iotova, V. (2010). Early growth patterns and long-term obesity risk. Curr. Opin. Clin. Nutr. Metab. Care 13, 294-299. doi: 10.1097/MCO. 0b013e328337d7b9

Torres, I. P., El Hafidi, M., Zamora-González, J., Infante, O., Chavira, R., and Baños, G. (2007). Modulation of aortic vascular reactivity by sex hormones in a male rat model of metabolic syndrome. Life Sci. 80, 2170-2180. doi: 10.1016/j.lfs.2007. 04.006

Tostes, R. C., Carneiro, F. S., Carvalho, M. H. C., and Reckelhoff, J. F. (2016). Reactive oxygen species: players in the cardiovascular effects of testosterone. Am. J. Physiol. Regul. Integr. Comp. Physiol. 310, R1-R14. doi: 10.1152/ajpregu. 00392.2014 
Vasudevan, H., Nagareddy, P. R., and McNeill, J. H. (2006). Gonadectomy prevents endothelial dysfunction in fructose-fed male rats, a factor contributing to the development of hypertension. Am. J. Physiol. Heart Circ. Physiol. 291, H3058-H3064. doi: 10.1152/ajpheart.00598.2005

Wang, C., Jackson, G., Jones, T. H., Matsumoto, A. M., Nehra, A., Perelman, M. A., et al. (2011). Low testosterone associated with obesity and the metabolic syndrome contributes to sexual dysfunction and cardiovascular disease risk in men with type 2 diabetes. Diabetes Care 34, 1669-1675. doi: 10.2337/dc102339

Yu, Z. B., Han, S. P., Zhu, G. Z., Zhu, C., Wang, X. J., Cao, X. G., et al. (2011). Birth weight and subsequent risk of obesity: a systematic review and meta-analysis. Obes. Rev. 12, 525-542. doi: 10.1111/j.1467-789X.2011.00867.x

Zamora-Mendoza, R., Rosas-Vargas, H., Ramos-Cervantes, M. T., Garcia-Zuniga, P., Perez-Lorenzana, H., Mendoza-Lorenzo, P., et al. (2018). Dysregulation of mitochondrial function and biogenesis modulators in adipose tissue of obese children. Int. J. Obes. 42, 618-624. doi: 10.1038/ijo.2017.274

Zhao, Y., Wang, S. F., Mu, M., and Sheng, J. (2012). Birth weight and overweight/obesity in adults: a meta-analysis. Eur. J. Pediatr. 171, 1737-1746.

Zhou, Y., Li, H., and Xia, N. (2021). The interplay between adipose tissue and vasculature: role of oxidative stress in obesity. Front. Cardiovasc. Med. 8:131. doi: 10.3389/fcvm.2021.65 0214

Conflict of Interest: The authors declare that the research was conducted in the absence of any commercial or financial relationships that could be construed as a potential conflict of interest.

Publisher's Note: All claims expressed in this article are solely those of the authors and do not necessarily represent those of their affiliated organizations, or those of the publisher, the editors and the reviewers. Any product that may be evaluated in this article, or claim that may be made by its manufacturer, is not guaranteed or endorsed by the publisher.

Copyright (C) 2022 Costa, Alves-Lopes, Alves, Servian, Mestriner, Carneiro, Lobato and Tostes. This is an open-access article distributed under the terms of the Creative Commons Attribution License (CC BY). The use, distribution or reproduction in other forums is permitted, provided the original author(s) and the copyright owner(s) are credited and that the original publication in this journal is cited, in accordance with accepted academic practice. No use, distribution or reproduction is permitted which does not comply with these terms. 